УДК 338.1: 007.5

\author{
Івченко Є.А.
}

\title{
КАУЗАЛЬНИЙ ХАРАКТЕР ТРАНСФОРМАЦІЙ В СИСТЕМІ ЕКОНОМІЧНОЇ БЕЗПЕКИ ПІДПРИЕМСТВА
}

\begin{abstract}
У статті визначено, щчо дослідження каузального характеру трансформацій у системі економічної безпеки підприємства спирається на причини змін у загальному розумінні, природу економічної безпеки як соціального та економічного феномену, а також на закономірності функціонування та розвитку систем різної природи. Виділено складові каузальної природи трансформацій в системі економічної безпеки підприсмства. Запропоновано опис впливу складових каузальної природи трансформацій у системі економічної безпеки підприємства на засадах біхевіоризму. Визначено, щуо трансформація має характер реакиії системи підприємства в цүілому та системи економічної безпеки на певний стимул.
\end{abstract}

Ключові слова: економічна безпека, система економічної безпеки, трансформація, каузальний, біхевіоризм, протиріччя, адаптація.

Постановка проблем. Сьогоднішні реалії функціонування потребують від підприємств впровадження сучасних інструментів захисту своїй діяльності, а забезпечення економічної безпеки стає однією із головних цілей управління. Система економічної безпеки $\epsilon$ важливою для підприємства, та стан економічної безпеки $\epsilon$ передумовою досягнення та збереження сталих фінансових результатів діяльності підприємства. Втім, властивість економічної безпеки не є підприємству іманентною, економічна безпека не виникає природно. Навпаки, через вплив значної кількості загроз та ризиків у внутрішньому та зовнішньому середовищі підприємства необхідними $\epsilon$ цілеспрямовані зусилля для забезпечення економічної безпеки підприємства, що можливе лише за умов трансформації. Визначення причини виникнення та умови протікання трансформаційного процесу в системі економічної безпеки підприємства дозволить підприємству розробити механізм протидії внутрішнім і зовнішнім загрозам, аналізувати складні соціально-економічні умови для вирішення стратегічних завдань підприємства, що зумовлює актуальність дослідження.

Аналіз останніх досліджень і публікацій. Актуальність дослідження трансформацій підприємства викликає зацікавленість багатьох вітчизняних та зарубіжних науковців. Проблематиці дослідження трансформацій підприємства висвітлені у працях таких науковців, як Т. Hannan, G. Carroll, Ю. М. Плотинского,

\footnotetext{
(C) Івченко Свген Анатолійович, к.е.н, доц., доцент кафедри менеджменту та маркетингу, Східноукраїнського національного університету імені В. Даля, тел.: +380509203373, e-mail: ivchenkoevg85@gmail.com
}

М. С. Дороніної,

С. Ю Козьменко,

В. С. Пономаренко, О. М. Тридіда та інші.

Дослідженню системи економічної безпеки підприємства приділено багато уваги у працях таких науковців, як Г. В. Козаченко, Ю. С. Погорелов, О. М. Ляшенко, Є. І. Овчаренко, О. В. Ілляшенко та інші.

Проте дослідженню причин виникнення трансформацій у системі економічної безпеки підприємства приділяється небагато уваги. Не висвітленим в науковій літератури залишається опис впливу та дослідження складових каузальної природи трансформацій у системі економічної безпеки підприємства. В таких умовах актуалізується проблема управління трансформаціями в системі економічної безпеки підприємства.

Формулювання цілей статті. Метою цієї статті є дослідження теоретичних підходів та методологічних засад каузального характеру трансформацій в системі економічної безпеки підприємства та їхнього впливу.

Опис основних результатів дослідження. Поняття трансформації постає доволі складним та багатогранним. Трансформаційні процеси $\epsilon$ невід'ємною частиною розвитку соціальноекономічних систем будь-якого рівня - від національної економіки до окремого підприємства. Розвиток, у свою чергу, $\epsilon$ необхідною умовою функціонування таких економічних систем у довгостроковому періоді.

Вважається, що поняття «трансформація» набуло широкого використання в суспільних науках у другій половині $\mathrm{XX}$ ст. для характеристики новітніх процесів, пов'язаних із радикальними структурними змінами національних економік [1, с.45]. Традиційно трансформація позначає зміну чого-небудь, перетворення системи різного масштабу, глибини, спрямованості, спричинені 
внутрішніми або зовнішніми факторами [2]. Т. I. Заславська, у свою чергу, пропонує розуміти трансформаційний процес як поступове, відносно мирне, але разом 3 тим глибоке й відносно швидке перетворення соціальної природи суспільства, обумовлене насамперед не зовнішніми факторами, а внутрішніми потребами системи [3]. Погоджуючись із такою точкою зору щодо природи трансформації, не можна обмежувати іiі джерела виключно факторами ендогенної природи, оскільки навіть простий лінійний причинно-наслідковий аналіз може підтвердити, що трансформація може відбуватися як під впливом внутрішніх стосовно об'єкту трансформації чинників, так і під впливом зовнішніх. 3 цього приводу, наприклад, C. А. Єрохін зазначає про рівноправний вплив як ендогенних, так екзогенних чинників на формування трансформаційного процесу [4]. Та ж сама точка зору щодо рівноправності ендогенних та екзогенних джерел виникнення трансформацій простежується в роботах $[5,6]$.

Більш загальною у такому випадку логічно визнати точку зору О. В. Корнуха i А. М. Турило [6], згідно якої трансформація $\epsilon$ економічною категорією, яка пов'язана 3 економічною сферою, притаманною різним рівням господарювання, відображає складний процес, що здійснюється одночасно в просторі і часі. О.В. Корнух зазначає, що економічна трансформація відбувається під впливом об'єктивних та суб'єктивних чинників, а ключовою iii ознакою $є$ сукупність змін, які в кінцевому підсумку призводять до нового економічного стану, нових економічних результатів та постановки нових економічних цілей та завдань [6, с.190].

Трансформація як процес може охоплювати не тільки широке коло об'єктів на підприємстві, підсистеми управління, але й функцій управління. Так, С.В. Філіппова та O.В. Добруля зазначають, що трансформаційні процеси поширюються на економічні інструменти управління, організаційні форми його здійснення, виробничі системи і учасників підприємства [5]. 3 такою точкою зору слід повністю погодитися, тим більш, що вона підкреслює важливий щодо природи трансформації на підприємстві аспект: така трансформація не може бути зосереджена в одній підсистемі підприємства, бути актуальною щодо одного виду використовуваних ресурсів тощо. Навіть якщо первинно трансформація планувалася щодо одного 3 елементів системи підприємства, іiі проведення буде неодмінно «зачіпати» інші елементи та підсистеми підприємства. 3 іншого боку, трансформація позначає не тільки процес перетворення, але й процес становлення, перетворення системи різного масштабу [1]. Внаслідок трансформації можуть відбуватися не тільки суто зміни, але й генезис нової системи, нових відносин або явищ. Трансформації в залежності від кінцевої мети і стану, змінюють підсистеми та взаємозв'язок елементів системи економічної безпеки підприємства, що потребує впровадження та контролю керованих змін.

Отже, за змістом трансформація приводить до певних змін, а за наслідками ї природа полягає у тому, що вони позначаються на стані різних систем. Економічна безпека підприємства 3 позицій системного підходу розглядається як самостійна система, що має структуру, сукупність елементів, зв'язки, взаємодію із зовнішнім та внутрішнім середовищем. Але за зв'язками завжди стоять процеси, які $\epsilon$ причиною розвитку та функціонування як системи економічної безпеки підприємства, так і систем взагалі. Економічна безпека як система представляє собою сукупність елементів, їхніх властивостей, взаємозв'язків і взаємовідносин, що складають єдиний комплекс і функціонують відповідно до певних об'єктивних закономірностей, що проявляються в конкретних історичних умовах. Ця система характеризується відносною відособленістю, особливою структурою i зв'язками 3 навколишнім середовищем, специфічним механізмом відтворення [2, с. 49]. Прийнято вважати, що система економічної безпеки підприємства $є$ невід'ємною частиною соціально-економічної системи. Соціальноекономічна система постійно знаходиться під впливом трансформаційних процесів, що зумовлюе зміну параметрів системи економічної безпеки підприємства. Зміна параметрів на макро-, мезо-, мікрорівні призводить до появи конкретної ситуації, що потребує відповідних аналітичних інструментів для іiі ідентифікації, оцінювання змін та розроблення управлінського рішення. Доволі часто трансформації системи економічної безпеки підприємства носять не повністю добровільний характер та зумовлені або змінами в зовнішньому середовищі підприємства, або зміною відносин підприємства із його зовнішнім середовищем (наприклад підприємство зростає, збільшується кількість контрагентів, виникають нові загрози, які для підприємства раніше були неактуальними тощо). Це породжує 
необхідність забезпечення необхідної реакції всіх підсистем підприємства та складових управління підприємством на ситуації, яка виникає. I якщо така система у своєму поточному стані не в змозі забезпечити необхідну реакцію, адаптуватися до змін у зовнішньому середовищі або до змін у відносинах підприємства та його зовнішнього середовища, то дієвість такої системи знижуватиметься аж до актуалізації нових загроз для підприємства.

Таким чином, дослідження природи трансформацій у системі економічної безпеки підприємства потребує, у тому числі, відповіді на питання, як такі трансформації виникають, i до яких наслідків вони приводять. Отже, виникає потреба у дослідженні каузального характеру трансформацій у системі економічної безпеки підприємства. Така назва походить від об'єднання транслітерацій двох англомовних слів - каузальний (від англ. «causal» - такий, що є причиною, причинний).

Дослідження каузального характеру трансформацій у системі економічної безпеки підприємства спирається на причини змін у загальному розумінні (трансформація за своїм характером $\epsilon$ зміною, і тому на неї поширюються загальні закономірності проходження змін), природу економічної безпеки як соціального та економічного феномену, а також на закономірності функціонування та розвитку систем різної природи. Монографічний аналіз $[8-14,19,20]$ дозволяє виділити такі складові каузальної природи трансформацій у системі економічної безпеки підприємства (рис. 1)

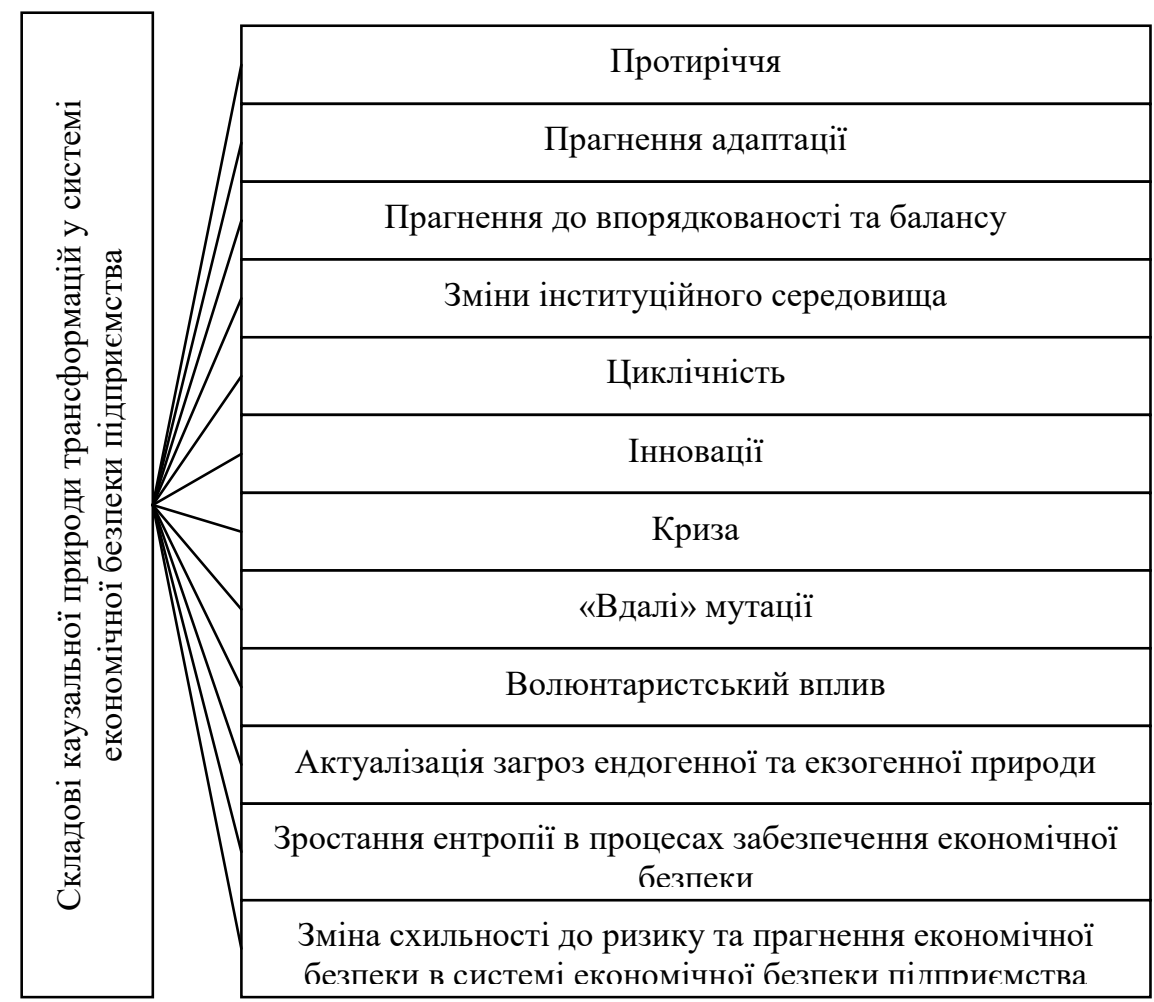

Рис. 1 . Складові каузальної природи трансформацій в системі економічної безпеки підприємства $[8-14,19,20]$

Всі виділені складові каузального характеру трансформацій в системі економічної безпеки підприємства фактично вписуються в біхевіористичну схему «Стимул - реакція». Така схема фактично є основою біхевіоризму як міждисциплінарного наукового напряму. У перекладі англійське слово «behavior» означає поведінка $[15$, с. 60$]$. Предметом психології в межах біхевіоризму визначалась не свідомість, а поведінка. Первісно біхевіоризм як наукова течія був сформований у психології у роботах Дж. Уотсона, Е.Толмена, Б. Скіннера,
Е. Торндайка, Г. Спенсера $[15,16]$. Д. Уотсон побудував свою психологічну теорію на підгрунті вчення I. П. Павлова про умовні рефлекси. Базуючись на ньому, вчений стверджував, що особистість $\epsilon$ сукупністю поведінкових реакцій i, таким чином, $\epsilon$ предметом научіння. Та чи інша поведінкова реакція виникає на певний стимул чи ситуацію. Цей процес біхевіористи описували такою формулою: $\mathrm{S}$ - R, де $\mathrm{S}$ - стимул; $\mathrm{R}$ - реакція [15, c. 61]. Формула «стимул-реакція», яку біхевіористи пропагували як пояснювальний 
принцип поведінки, передбачала, що з людини можна виліпити що завгодно, якщо давати їй відповідні стимули, позитивно підкріплювати певні реакції [16, с. 60]. Таким чином, всі види поведінки - це навички, набуті у процесі ефективного повторення деяких дій у відповідь на зовнішні чи внутрішні подразники [16, с.61].

Попри той факт, що біхевіоризм отримав свій початок у психології, згодом він вийшов за ii межі, отримав імплементацію у різних галузях знання, й у тому числі отримав використання у сек'юрітології $[17,18]$. Отже на засадах біхевіоризму складові каузального характеру трансформацій в системі економічної безпеки підприємства фактично є стимулами проведення (рис. 2.X)

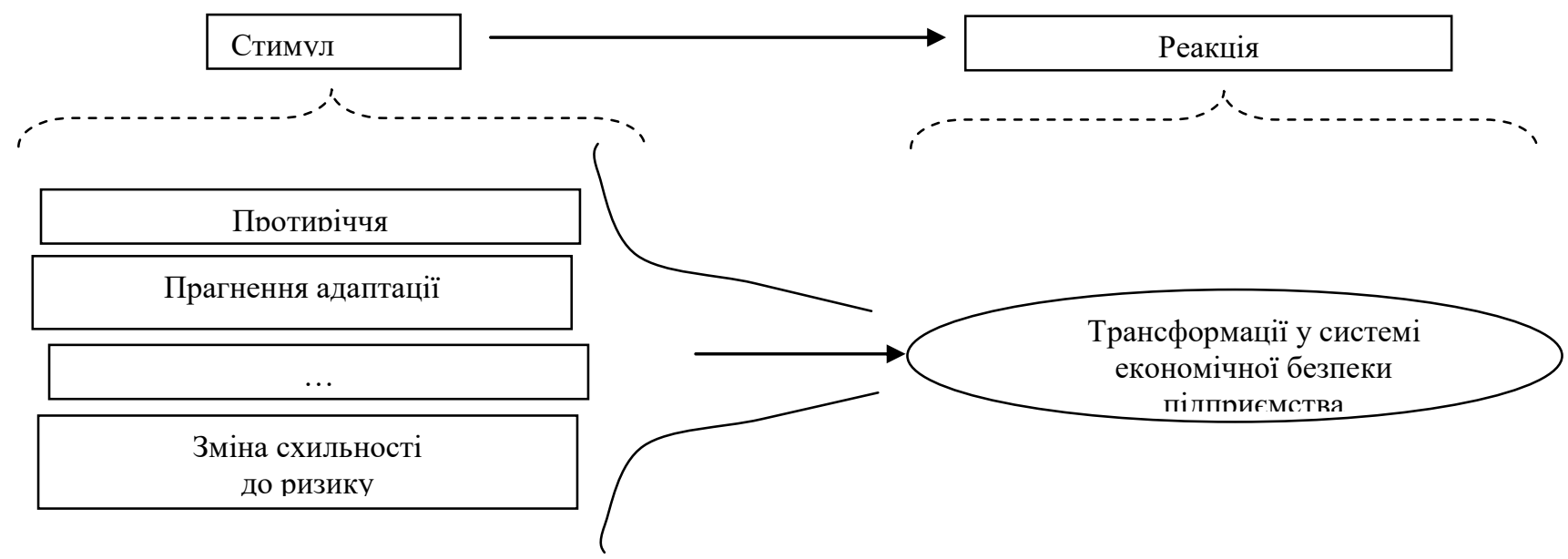

\section{Рис. 2. Опис впливу складових каузальної природи трансформацій у системі економічної безпеки підприсмства на засадах біхевіоризму* \\ * Запропоновано автором}

Доволі часто трансформації в системі економічної безпеки підприємства носять не повністю добровільний характер та зумовлені або змінами в зовнішньому середовищі підприємства, або зміною відносин підприємства із його зовнішнім середовищем, що мають каузальний характер. Слід зазначити, що стимули щодо формування трансформацій $\epsilon$ різними, можуть впливати паралельно, але головне у сформованій схемі (рис. 2) виникнення самих трансформацій як певної реакції з боку системи економічної безпеки підприємства. У такому випадку $\epsilon$ цілком очевидним, що трансформація вже має характер реакції системи економічної безпеки підприємства або у вигляді функціональної реакції (реакція дії, якщо можливості системи дозволяють відреагувати та такі загрози), або у вигляді змістової реакції (зміна системи, якщо поточний стан системи не дозволяе відреагувати на такі загрози).

Висновки та перспективи подальших досліджень. Таким чином, трансформації у системі економічної безпеки підприємства не $\epsilon$ самоціллю, вони призначені (у разі їхнього керованого характеру) для удосконалення стану системи, набуття нею нових функціональних можливостей, виконання ऑiі основних завдань тощо. I в управлінні підприємством 3 метою забезпечення дієвості такої системи важливо, щоб такі трансформації були керовані, проходили внаслідок цілеспрямованого впливу 3 боку суб'єктів управління в системі підприємством.

Трансформації у системі економічної безпеки підприємства можуть проходити та визначатися різною інтенсивністю, швидкістю, але важливим завданням є визначення впливу складових каузальної природи трансформацій. Отже, використання засад біхевіоризму для опису впливу складових каузальної природи трансформації у системі економічної безпеки підприємства у такому разі постає методологічно цілком правомірним. I у разі використання такого тезаурусу заслуговує на увагу опис як стимулів, так і реакцій щодо формування трансформацій у системі економічної безпеки підприємства. Опис впливу складових каузальної природи трансформацій на засадах біхевіоризму дозволяє відповісти на питання, як такі трансформації виникають, і до яких наслідків вони приводять. 3 цієї точки зору сама трансформація вже має характер реакції системи підприємства в цілому та системи економічної безпеки на певний стимул. Тому подальших досліджень потребує вивчення питання не тільки каузального, але й 
консеквентного характеру трансформацій у системі економічної безпеки підприємства. При цьому таке питання заслуговує на увагу як у прескриптивному аспекті (дослідження очікуваних результатів трансформацій в системі економічної безпеки підприємства внаслідок здійснюваних дій), так і у дескриптивному (вивчення та моніторинг фактичних результатів трансформацій).

\section{ПЕРЕЛІК ВИКОРИСТАНИХ ДЖЕРЕЛ}

1. Радіонова О. М. Зайнятість у великих містах: сучасний економіко-теоретичний аналіз : монографія /О.М. Радіонова;Харк. нац. ун-т міськ. госп-ва ім. О. М. Бекетова. - Х. : ХНУМГ, 2014. - 178 с.

2. Поченчук, Г. М. Закономірності трансформаційних процесів національної економіки [Текст] / Галина Михайлівна Поченчук // Економічний аналіз : зб. наук. праць / Тернопільський національний економічний університет; редкол. : В. А. Дерій (голов. ред. ) та ін. - Тернопіль : Видавничо-поліграфічний центр Тернопільського національного економічного університету “Економічна думка", 2014. - Том 16. - № 1. C. $123-129$.

3. Загороднюк Т. Концепции постсоветской трансформации общества Т.И. Заславской и Н.В. Паниной : Мон. - К.: Институт социологии НАН Украины, 2013. - 164 с.

4. Єрохін С. А. Трансформаційний процес та його структуризація / С. А. Єрохін // Актуальні проблеми економіки. - 2005. - № 2 (44). - С. 4-12.

5. Філіппова С. В. Фінансові проблеми трансформаційних процесів у промисловому секторі економіки України / С. В. Філіппова, О. О. Добруля // Вісник Національного університету "Львівська політехніка". 2007. - № 606 : Менеджмент та підприємництво в Україні: етапи становлення і проблеми розвитку. - С. $430-$ 434.

6. Корнух О.В. «Економічна трансформація» як ключове поняття сучасного громадського розвитку / О.В. Корнух, А.М. Турило // Науковий вісник Херсонського державного університету. 2014. — № 6, частина 3. - C. 189-191.

7. Гуменюк А. М. Безпека структурно-інституціональної трансформації економіки регіону: теоретичні основи та прикладні аспекти : монографія / Анатолій Маркович Гуменюк. - К. : НІСД, 2014. - 468 с.

8. Дороніна М.С. Управління економічними та соціальними процесами підприємства. Монографія. Харків: Вид. ХДЕУ, 2003. - 444 с.

9. Маркіна I.А. Методологія сучасного управління : Монографія. - К.: Вища шк., 2001. - 311 с.

10. Плотинский Ю.М. Модели социальных процессов: Учебное пособие для высших учебных заведений. - 2-е изд., доп. и перераб. - М.: Логос, 2001. - 296 с.

11.Пономаренко В.С., Тридід О.М., Кизим М.О. Стратегія розвитку підприємства в умовах кризи: Монографія. - Харків: ІНЖЕК, 2003. - 328 с.

12. Погорелов Ю.С. Природа, рушійні сили та способи розвитку підприємства / Ю.С. Погорелов. Харків: АдвА, 2010. - 352 с.

13. Рудніченко Є. М. Оцінювання та моделювання впливу суб'єктів митного регулювання на систему економічної безпеки підприємства: [монографія] / Є.М. Рудніченко. — Луганськ: Промдрук, 2014 - 389 с.

14. Овчаренко Є. I. Система економічної безпеки підприємства: формування та цілепокладання : [монографія] / Є. І. Овчаренко. - Лисичанськ: "ПромЕнерго", 2015. — 483 с.

15. Варій М. Й. Загальна Психологія: навч. пос. [для студ. вищ. навч. закл.]/ М. Й. Варій - [3-те вид.]. - К. : Центр учбової літератури, 2009. - 1007 с.

16. Психологія: навчальний посібник / Т.В.Іванова, О.А. Кривопишина, П.І. Сахно та ін.; за заг. ред. Л.М. Кудояра. - Суми: Сумський державний університет, 2011. - 331 с.

17. Гавловська Н. I. Економічна безпека зовнішньоекономічної діяльності промислових підприємств: оцінювання, моделювання, механізм забезпечення : монографія / Н. І. Гавловська. - Хмельницький : ФОП Мельник А. А., 2016. - 480 c.

18. Pogorelov Y.S., Havlovska N.I. Formation of the behavioural model of the economic security mechanism functioning concerning foreign economic activities within the system of enterprise management // Black Sea scientific journal of academic researches. - 2016. - Vol. 32, Issue 06. - P. 9-14

19. Hannan M.T., Freeman J. Organizational Ecology. - Cambridge. MA: Harvard University Press, 1989. $384 \mathrm{p}$.

20. Carroll, G.R., Hannan M.T. The Demography of Corporations and Industries. - Princeton, NJ: Princeton University Press, 2000. - $552 \mathrm{p}$

\section{REFERENCES}

1. Radionova O. M. (2014) Zainiatist u velykykh mistakh: suchasnyi ekonomiko-teoretychnyi analiz [Employment in big cities: modern economic and theoretical analysis].- Kharkiv: KhNUMH [in Ukrainian].

2. Pochenchuk H. M. (2014) Zakonomirnosti transformatsiinykh protsesiv natsionalnoii ekonomiky [The regularties of the transformational processes of the national economy]. -Ekonomichnii analiz: zbirnyk naukovykh 
pratc - Economic analysis: a collection of scientific work, 1, vol. 16, 123-129.Ternopil: Ekonomichna Dumka [in Ukrainian].

3. Zagorodniuk T. (2013) Kontceptcii postsovetskoi transformatcii obshchestva T. I. Zaslavskoi i N. V. Paninoi [Concepts of post-Soviet society transformation T. I. Zaslavskaya and N. V. Panina].-Kiev: Institut sotciologii NAN Ukrainy [in Russian].

4. Yerokhin S.A. (2005) Transformaciinyi proces ta yoho strukturyzaciia [Transformation process and its structuring]. - Aktualni problemy ekonomiky, 2 (44), 4-12 [in Ukrainian].

5. Filippova S., Dobrulia O. (2007) Finansovi problemy transformatsiinyh protsesiv u promyslovomu sektori ekonomiky Ukrainy [Financial problems of transformation processes in the industrial sector of Ukrainian economy]. - Visnyk Natsionalnoho universytetu "Lvivs'ka politekhnika"- Bulletin of the National University "Lviv Polytechnic", 606, 430-434 [in Ukrainian].

6. Kornuh O. V., TuryloA. M. (2014) «Ekonomichna transformaciia» iak kliuchove poniattia suchasnoho hromadskoho rozvytku ["Economic transformation" as a key concept of contemporary social development]. Naukovyi visnyk Hersonskoho derzhavnoho universytetu - Scientific Bulletin of Kherson State University, 6, part 3, 189-191 [in Ukrainian].

7. Humeniuk A. M. (2014) Bezpeka strukturno-instytutsionalnoi transformatsii ekonomiky rehionu: teoretychni osnovy ta prykladni aspekty [Security of structural and institutional transformation of the region economy: the theoretical basis and applied aspects]. - Kyiv: National Institute for Strategic Studies (NISS)[in Ukrainian].

8. Doronina M. S. (2003) Upravlinnia ekonomichnymy ta socialnymy protsesamy pidpryiemstva [Management of economic and social processes of the enterprise] - Kharkiv: Vyd. HDEU [in Ukrainian].

9. Markina I. A. (2001) Metodolohiia suchasnoho upravlinnia [Methodology of modern management]. - Kyiv: Vyshhashk[in Ukrainian].

10. Plotinskii Iu. M. (2001) Modeli sotcialnykh protcessov: Uchebnoe posobye dlja vysshyh uchebnyh zavedenyj [Models of social processes: Textbook for higher educational institutions]. - Moskva: Logos [in Russian].

11. Ponomarenko V. S., Trydid O. M., KyzymM. O. (2003) Stratehiia rozvytku pidpryiemstva v umovah kryzy [Strategy of enterprise development in conditions of crisis]. - Kharkiv: INZhEK [in Ukrainian].

12. Pohorelov Yu.S. (2010) Pryroda, rushiini syly ta sposoby rozvytku pidpryiemstva [Nature, driving for ces and ways of enterprise development]. — Kharkiv: AdvA, 2010 [in Ukrainian].

13. Rudnichenko Ye. M. (2014) Otsiniuvannia ta modeliuvannja vplyvu subiektiv mytnoho rehuliuvannia $n$ asystemu ekonomichnoi bezpeky pidpryiemstva [Evaluation and modeling of thein fluence of subjects of customs regulation on the system of economic security of the enterprise — Luhans'k: Promdruk[in Ukrainian].

14. OvcharenkoYe. I. (2015) Systema ekonomichnoi bezpeky pidpryiemstva: formuvannia ta tsilepokladannia [System of economic security of the enterprise: development and goal-setting]. - Lisichansk: "PromEnerho" [in Ukrainian].

15. Varii M. J. (2009) Zahalna Psyholohiia: navchalnyi posibnyk [General Psychology: tutorial]. - Kyiv: Centr uchbovoi literatury [in Ukrainian].

16. IvanovaT. V., Kryvopyshyna O.A., SahnoP. I. (2011) Psyholohiia: navchalnyi posibnyk [Psychology: a textbook]. L. M. Kudojara (Ed.). - Sumy: Sumskyi derzhavnyi universytet [in Ukrainian].

17. Havlovska N. I. (2016) Ekonomichna bezpeka zovnishnoekonomichnoi diialnosti promyslovyh pidpryiemstv: otsiniuvannia, modeliuvannia, mehanizm zabezpechennia [Economic security of foreign economic activity of industrial enterprises: evaluation, modeling, mechanism of support]. - Khmelnytskyi : FOP Melnyk [in Ukrainian].

18. Pogorelov Y. S., Havlovska N. I. (2016) Formation of the behavioural model of the economic security mechanism functioning concerning foreign economic activities with in the system of enterprise management // Black Sea scientific journal of academic researches, vol. 32, issue 06, 9-14 [in English].

19. Hannan M. T., Freeman J. (1989) Organizational Ecology. - Cambridge. MA: Harvard University Press[in English].

20. Carroll, G. R., Hannan M. T.(2000) The Demography of Corporations and Industries. - Princeton, NJ: Princeton University Press [in English].

Одержано 15.09.2017 p. 